\title{
International Disaster Law at the Domestic Level
}

\author{
The Philippines
}

\author{
Pauline Agatha Caspellan*
}

\section{1 \\ Introduction}

The Philippines was consistently ranked among the top three countries with the highest number of COVID-19 cases in Southeast Asia during 2020. ${ }^{1}$ Since 15 March 2020 up to the time of writing, the entire country has been placed in a 'community quarantine', the official term used for a lockdown, with varying levels of restrictions dependent on the rate of viral transmission and the coping capacity of public health facilities in the affected areas. ${ }^{2}$

The legal framework that forms the basis for the government's Covid-19 pandemic response is a fusion of laws and regulations rooted in public health management and disaster risk management (DRM) paradigms. The response measures consist of restrictions to the freedom of movement, imposition of curfew, restrictions on international and domestic travel, the mandatory use of face masks and face shields, prolonged closures of schools, offices and commercial establishments, prohibition on mass gatherings, and the use of disaster risk management funds and mechanisms to support social protection measures addressing CoviD-19's non-health impacts. CoviD-19 executive issuances and emergency laws also state that the pandemic's impacts are sufficient to declare a nationwide state of calamity. The same policy rationale that justifies the declaration of a nationwide state of calamity is also reflected in subsidiary legislation detailing CovID-19 coordination mechanisms and public funding that partly utilised DRM structures and financial resources. Furthermore, recent updates in disaster legislation in the Philippines highlight the momentum

* IFRC Disaster Law Adviser for Southeast Asia.

1 Catalian Ricci Madarang, 'Philippines enters list of top 20 countries with COVID-19 despite more than 200 days of lockdown', Interaksyon (Manila, o2 October 2020) <https:// interaksyon.philstar.com/trends-spotlights/2020/10/o2/177993/philippines-enters-list-of -top-2o-countries-with-covid-19-despite-more-than-20o-days-of-lockdown/> last accessed (as any subsequent URL) on 22 August 2021.

2 The following terms have been used to categorise the lockdowns, from the strictest to the least strict category: enhanced community quarantine (ECQ), modified enhanced community quarantine (MECQ), general community quarantine (GCQ), and modified general community quarantine (MGCQ). Other terminologies have also been used in ad-hoc cases, e.g. granular lockdown, GCQ with heightened restrictions. 
provided by CoviD-19 in institutionalising the Bangkok Principles for the implementation of the health aspects of the Sendai Framework for Disaster Risk Reduction 2015-2030 in national legislation, particularly by integrating DRM and health measures for the COVID-19 response.

\section{Overview of Disaster Laws in the Philippines}

The Philippines' core DRM law is Republic Act No. 10121 or the Philippine National Disaster Risk Reduction and Management Act of 2010 (NDRRM Act). It was passed after Typhoon Ketsana led to unprecedented flooding and loss of lives in Metro Manila in 2009. It succeeded an outdated law, Presidential Decree No. 1566, which had earlier established the National Disaster Coordinating Council (NDCC) in the 1970s and which had been drafted based on a traditional emergency response approach that was prevalent at that time. The passage of the NDRRM Act more than two decades later was largely seen as a positive outcome of law reform initiatives led by government and civil society actors to align the Philippines' disaster law with the precursor to the Sendai Framework, namely the Hyogo Framework for Action 2005-2015 (HFA). In particular, the NDRRM Act features a multi-hazard approach to disasters, places greater importance on disaster risk prevention and mitigation, contains some level of climate change integration, decentralises preparedness and response measures, and mandates the conduct of risk assessments, as had been espoused by the HFA.

This was a substantial development from Presidential Decree No. 1566 which, while generally focused on preparedness, still framed DRM from the standpoint of emergency response. This framing was due in part to the roots of the Philippines' DRM structure in civil defense. Prior to the creation of the NDCC, the National Civil Defense Administration and the National Civil Defense Council were established in 1954 to formulate and carry out the civil defense programme ' $[\mathrm{i}] \mathrm{n}$ the event of war directly involving the Philippines or other national emergency of equally grave character'. As the risk of natural hazards became ever more serious and frequent, the function of the Office of Civil Defense was broadened to include disaster preparedness and response. ${ }^{3}$

The development in DRM policy, particularly the shift to a multi-hazard and risk-informed approach to DRM, is reflected in the structure of the NDRRMC

3 Republic of the Philippines, Letter of Implementation No. 19, 'Relative to Chapter II, Part XIX on Department of National Defense and Other Pertinent Provisions of the Integrated Reorganization Plan' (31 December 1972). 
which expanded to 44 member government agencies, civil society and the private sector, reflecting broader participation and mainstreaming of resilience. It has four Vice-Chairpersons each of whom represents a thematic pillar in DRM. ${ }^{4}$

\section{Developments in 2020: Legislation for the Management of COVID-19 as a Biological Hazard}

\subsection{Treatment of CoviD-19 as a Disaster Caused by a Biological Hazard}

The two primary COVID-19 emergency laws, Republic Act No. 11469 or the Bayanihan ${ }^{5}$ to Heal as One Act ${ }^{6}$ ('Bayanihan I') and Republic Act No. 11494 or

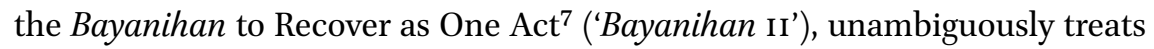
COVID-19 as a public health emergency (PHE). The laws are based primarily on the people's right to health, ${ }^{8}$ the President's constitutional power to declare a state of national emergency, ${ }^{9}$ and powers necessary for the protection of the general welfare. ${ }^{10}$ Both Bayanihan I and II refer to wHo guidelines and best practices as a basis for the President's emergency powers, and both cover coordination, notification, surveillance, detection, case management, monitoring and reporting actions indicated among the IHR core capacities. In addition to this, the current legal framework also treats CoviD-19 as a disaster caused by a biological hazard. For instance, while these laws do not directly refer to COVID-19 as a disaster, their description of the pandemic falls squarely into one, where the laws declare it as a 'serious threat to the health, safety, security, and lives of our countrymen, the long-term adverse effects on their means of livelihood, and the severe disruption of economic activities ..., ${ }^{11}$ the exact

$4 \quad$ These are the Secretary of Science and Technology for disaster prevention and mitigation; the Secretary of Interior and Local Government for preparedness; the Secretary for Social Welfare for response; and the Secretary of Socioeconomic Planning for recovery and rehabilitation.

5 'Bayanihan' is a Filipino word which means the culture of helping each other as a community.

6 Congress of the Philippines, Republic Act. No. 11469, 'Bayanihan to Heal As One Act' (24 March 2020).

7 Congress of the Philippines, Republic Act. No. 11494, 'Bayanihan to Recover As One Act' (11 September 2020).

8 The 1987 Constitution of the Republic of the Philippines (11 February 1987), art. 2, sec. 15.

$9 \quad$ Ibid., art. 6, sec. 23, para. 2.

$10 \quad$ Ibid., art. 2, sec. 5 .

11 RA 11469 (n 6) sec. 2, para 2. 
conditions which define a disaster under the NDRRM Act. ${ }^{12}$ This premise is more clearly supported by the operational DRM-related provisions of the COVID-19 emergency laws, such as the use of DRM funds, disaster-time remedial measures such as anti-hoarding and price control, regulation of relief, and provision of cash assistance and essential goods to households suffering from the non-health impacts of the pandemic, particularly loss of income due to the community quarantine.

\subsection{Emergency Powers Triggered by the Declaration of a State of Calamity and State of $\mathrm{PHE}$}

The declaration of a state of calamity for CoviD-19, first enacted in March 2020, was necessary to trigger the exercise of emergency powers under the NDRRM Act which helped to address the pandemic, the most important of which is the expedited release of quick response funds $(\mathrm{QRF})$ lodged in national (NGA) and local government units (LGU), to be spent for CoviD-19 measures. Notably, there had been other instances where a state of calamity was declared to address health risks, though these were done only at the level of the affected LGU. ${ }^{13}$

Similarly, the declaration of PHE under the Republic Act No. $1133^{2}$ or the Mandatory Reporting of Notifiable Diseases \& Health Events of Public Health Concern Act ('domestic IHR law') authorises the President to mobilise both governmental and non-governmental agencies to respond to the threat. ${ }^{14}$ The law was enacted in compliance with IHR 2005 and provides legal basis for establishing some of the IHR core capacities, such as coordination, surveillance, response, risk communication, and human resources. ${ }^{15}$ In addition to establishing 'disease surveillance and response systems of the Department of Health and local counterparts as a first line of defense against epidemics and

12 See RA 10121, sec. 3 which defines a disaster as 'a serious disruption of the functioning of a community or a society involving widespread human, material, economic or environmental losses and impacts, which exceeds the ability of the affected community or society to cope using its own resources [...]'.

13 See Marna Dagumboy del Rosario, 'Pampanga placed under state of calamity due to avian flu virus' (Philippine News Agency 11 August 2017) $7<$ https://www.pna.gov.ph/ articles/1005893>; see also Mar Serrano, 'Catanduanes now under state of calamity due to dengue' (Philippine News Agency o3 September 2019) <https://www.pna.gov.ph/ articles/1079477>.

14 Congress of the Philippines, RA 11332, sec. 7.

15 Ibid, sec. 2, para. 1, which lays down the State's policy to 'endeavor to protect the people from public health threats through the efficient and effective disease surveillance [...] in compliance with the 2005 International Health Regulations (IHR) of the World Health Organization (wHo)'. 
health events of public health concern', 16 it also criminalises "non-cooperation" in the reporting and notifying of notifiable diseases and health events of public concern. ${ }^{17}$

The earliest executive issuances of the President were the declaration of a state of PHE and the declaration of a state of calamity due to COVID-19. Presidential Proclamation No. $922^{18}$ declared the existence of a PHE after the Department of Health confirmed the first case of local covid-19 transmission ${ }^{19}$ most of which were concentrated in Metro Manila. Presidential Proclamation No. $929^{20}$ declared a national state of calamity, citing the need to access DRM funds and implement remedial measures under the NDRRM Act to support the pandemic response. This is reflected in the policy rationale for the declaration of a state of calamity, wherein NGAS and LGUs are given 'ample latitude to utilise appropriate funds, including the QRF, in their disaster preparedness and response efforts to contain the spread of COVID-19.21

\subsection{DRM Coordination Mechanisms Utilised for the coVID-19 Response}

The Philippines utilised two primary coordination mechanisms for the management of COVID-19. The first is the Inter-agency Task Force on the Management of Emerging Infectious Diseases (IATF-MEID) which was established in 2014 and is led by the Secretary of Health. ${ }^{22}$ It is primarily an inter-sectoral public health coordination platform tasked to establish a system of contact tracing, border control, general prevention of local transmission (i.e. contact tracing, quarantine, isolation, study of viral exposure), capacitate health care facilities and professionals, lead public awareness campaigns regarding EIDs, and notify WHO as to the existence of an EID. ${ }^{23}$ For COVID19, the role of the IATF-MEID was narrowed down to policy-making where it is specifically tasked as the 'policy-making body of operations'. It has the power

\footnotetext{
$16 \quad$ Ibid., sec. 2, para. 2.

17 Ibid., sec. 9.

18 Republic of the Philippines, Presidential Proclamation No. 922, 'Declaring a State of Public Health Emergency Throughout The Philippines' (2020).

19 See Republic of the Philippines, NDRrmc Resolution No. 2 (2020) which recommended to the President the declaration of a state of calamity due to the CoviD-19 pandemic.

20 Republic of the Philippines, Presidential Proclamation No. 929, 'Declaring a State of Calamity Throughout The Philippines Due to Corona Virus Disease 2019' (2020).

21 See also Republic of the Philippines, Department of Budget and Management Local Budget Circular No 124, Policy Guidelines on the Provision of Funds by Local Government Units for Programs, Projects, and Activities to Address the Coronavirus Disease (covid19) Situation (2020).

22 Republic of the Philippines, Executive Order No. 168 (2014).

23 Ibid., sec. 2 (a).
} 
to review and revise the overall guidelines governing the community quarantine, though in some cases it still refers certain decisions to the Office of the President for approval (e.g. inbound international travel quotas). ${ }^{24}$

The responsibility to coordinate the implementation of the COVID-19 response was lodged in a separate coordination mechanism, the National Task Force for COVID-19 (NTF COVID-19). ${ }^{25}$ The NDRRMC activated the NTF COVID-19 structure upon its adoption of the CoviD-19 National Action Plan, ${ }^{26}$ and the NDRRMC itself was responsible for identifying its member government agencies. ${ }^{27}$ While the NTF CoviD-19 operates within the structure of the NDRRMC, their structures are not entirely similar. Both the NTF COVID-19 and the NDRRMC are chaired by the Secretary of National Defense, with the Office of Civil Defense serving as their secretariat. The National Incident Command of the NTF COVID-19 also operates within the NDRRMC emergency operations centre. However, their structures differ in that the NTF COVID-19 has three primary clusters - the Response Cluster, Vaccine Cluster, and Recovery Cluster - that are further sub-divided into various 'task groups' responsible for varying pandemic response measures, ${ }^{28}$ whereas the NDRRMC is grouped across the DRM thematic pillars of prevention and mitigation, preparedness, response, and recovery, and may further activate eleven humanitarian clusters based on a localised version of the IASC cluster approach. ${ }^{29}$

\subsection{Integration of Health Risk in DRM Plans}

The NDRRM Act includes biological hazards within its scope, but does not provide the details for addressing disasters caused by biological hazards which requires additional measures than those normally implemented in other types of disasters, significantly the deprivation of liberty through mandatory

24 Republic of the Philippines, Executive Order No. 112 (2020).

25 See Republic of the Philippines IATF-MEID Resolution No. 15 (2020) which adopted the Covid-19 National Action Plan.

26 See NDRRMC Memorandum Circular No. 54 (2020) which provides that ' $t$ the operationalization of the National Action Plan for COvID-19 activated the NDRRMC as the National Task Force in which the functions of the Response Clusters are harmonized to the said plan, serving as Task Groups, Sub-Task Groups and Task Units of the National Incident Command'.

27 See Republic of the Philippines IATf-Meid Resolution No. 15 (2020), para. A, subpara. 5 (b) which states that ' $[t]$ he NDRRMC shall determine and identify the agencies to the new units of the proposed NTF COVID-19 organizational structure'.

28 Republic of the Philippines NTF COVID-19, 'National Action Plan for COVID-19 Phase III' (NDRRMC Website, 2021) <https://ndrrmc.gov.ph/index.php/2014-o9-O5-05-49-57/9-ndrr mc-advisory/4148-national-action-plan-against-covid-19.html>.

Republic of the Philippines, NDCC Memorandum No. 12 (2008). 
isolation or quarantine orders, prolonged restrictions on domestic and international travel, restrictions on business operations, and limitations on social activities. Notably, the disruption brought about by CoviD-19 provided the imperative to integrate biological hazards in DRM plans, hence the NDRRMC ordered the revision of public service continuity and contingency plans to include COVID-19 risks and other biological hazards. ${ }^{30}$ This required that plans be adjusted to address disaster scenarios while pandemic restrictions are still in place. Plans must also include biological hazards in the regular course of risk assessments as well as in the safety protocols of emergency responders.

\subsection{Use of DRM Funds for covID-19 Response}

A key consequence of the declaration of a state of national calamity ${ }^{31}$ and the enactment of the COVID-19 emergency laws is the inclusion of national and local DRRM budgets within the larger pool of government funds that can be spent for the pandemic response. ${ }^{32}$ Given this broadened purpose, the COVID-19 emergency laws allocated a portion of the legislated COviD-19 funds to augment the National DRRM funds (NDRRM Fund). These laws also liberalised the use of national and local QRF during the pandemic by removing the $30 \%$ ceiling set by the NDRRM Act. ${ }^{33}$ By May 2020, about $41 \%$ of the entire NDRRM Fund was utilised for the CoviD-19 response since Bayanihan I had been enacted in March. ${ }^{34}$

\subsection{The Auxiliary Role of the Red Cross in Health and DRM}

Lastly, both laws laid down a clear legal basis for the auxiliary role of the Philippine Red Cross Society in the 'distribution of goods and services incidental in the fight against CoviD-19. ${ }^{35}$ The auxiliary role to support, supplement or, in some cases, substitute government services in the humanitarian field, is a

30 See Republic of the Philippines, NDrrmc Memorandum Order No. 54 (2020); see also Republic of the Philippines, NDRRMC Memorandum Order No. 57 (2020).

$31 \quad$ Presidential Proclamation No. 929 (n 20).

32 See Bayanihan II (n 7) sec. 10, which shows that compared to NDRRM Funds used for COVID-19, a substantially bigger portion of the COVID-19 funds were raised from reprogrammed, realigned and reallocated funds under the General Appropriations Act of 2020, and other unspent or unreleased government funds of NGAS and government owned or controlled corporations.

33 Bayanihan I (n 6) sec. 4(dd); Bayanihan II (n 7) sec. 4(yy).

34 See 'Explainer: 2020 and 2021 NDRRM Fund Utilization' (Office of Civil Defense Website, 04 May 2020) <https://ocd.gov.ph/index.php/news/743-explainer-202O-and -2021-ndrrm-fund-utilization>.

35 Bayanihan I (n 6) sec. 4 (l); Bayanihan II (n 7) sec. 4 (v). 
suigeneris status granted to National Red Cross and Red Crescent Societies and is applicable to their humanitarian work both in PHE and DRM.

\section{$4 \quad$ Linkage to International Disaster Law Norms}

\subsection{Linkage to the SFDRR Bangkok Principles and WHO Health-EDRM Framework}

International legal norms and standards on the management of disaster risk caused by biological hazards have had some progress in recent years, both in disaster risk management and public health paradigms.

The Hyogo Framework for Action 2005-2015 and the 2009 UNISDR Terminology on Disaster Risk Reduction ${ }^{36}$ defined hazards to include biological hazards, ${ }^{37}$ while the Sendai Framework for Disaster Risk Reduction 2015-203O (SFDRR) ${ }^{38}$ and the Bangkok Principles for the implementation of the health aspects of the Sendai Framework ('Bangkok Principles') were the first instruments to provide concrete actions to address biological hazards and other public health risks as an integral part of disaster risk management at the global, national and local level..$^{39}$ The Bangkok Principles were adopted in 2016 to provide non-binding standards and actions to guide the accomplishment of SFDRR health-related targets. ${ }^{40}$ These are the substantial decrease in disaster mortality, the substantial reduction of the number of disaster-affected people, and the substantial reduction of disaster damage to critical infrastructure and disruption of basic services including health facilities. ${ }^{41}$ The Bangkok

$36 \quad$ United Nations Office for Disaster Reduction (2009), 'UNISDR Terminology on Disaster Risk Reduction' (May 2009). The list of terminologies was later on updated in 2016, where it continued to include biological hazards. See United Nations General Assembly, 'Report of the Open-Ended Intergovernmental Expert Working Group on Indicators and Terminology Relating to Disaster Risk Reduction' (1 December 2016) A/71/644.

This is found in the commentary to the term 'hazards', which states that ' $\mathrm{t}]$ he hazards of concern to disaster risk reduction as stated in footnote 3 of the Hyogo Framework are "... hazards of natural origin and related environmental and technological hazards and risks." Such hazards arise from a variety of geological, meteorological, hydrological, oceanic, biological, and technological sources, sometimes acting in combination'.

38 UN, 'Sendai Framework for Disaster Risk Reduction 2015-2030' (18 March 2015) UN Doc A/CONF.224/CRP.1.

39 Ibid., Preamble, para. 15.

40 See the 'About the Conference' section of the website for the International Conference on the Implementation of the Health Aspects of the Sendai Framework for Disaster Risk Reduction 2014-2030 (10-11 March 2016) <https://www.unisdr.org/conferences/2016/ health>.

UNDRR, SFDRR, para 18, sub-paras a, b, and d (2016). 
Principles have two key components. The first one sets out principles and actions that support resilient health systems - specifically the continuity of health services and the prevention of aggravated health risks - within disaster risk management frameworks. In this context, health is understood as one among many cross-cutting sectors which may be negatively affected by disaster risk. The second component covers principles and actions which squarely regulate biological hazards as a causal factor of disaster risk itself.

In 2019, WHO adopted the Health-EDRM Framework which sets out the standards for certain 'functions in health and other sectors that collectively reduce the health risk and consequences' arising from disasters and other emergencies.'42 It was not designed to address disasters "resulting" from biological hazards. Rather, it focuses on preventing and managing aggravated health risks arising from disasters, such health risks possibly being in the form of a pandemic which occurs during or as a result of a separate disaster event. However, despite this limited intention, the framework clearly highlights the importance of the IHR 2005 public health measures - which were the same ones applied in the Philippine's Covid-19 response, such as isolation, quarantine, school closures, the prohibition on mass gatherings, and immunization. ${ }^{43}$

Despite said limitations, the Bangkok Principles and the wHO Health-EDRM Framework are complementary since both instruments address health risks as a factor of disasters, therefore both are relevant to understanding and assessing COVID-19 legislation in the Philippines. ${ }^{44}$ UNGA Resolution 74/2018 on $\mathrm{DRR}^{45}$ also 'recognises that biological hazards require strengthened coordination between disaster and health risk management systems in the areas of risk assessment, surveillance and early warning'. Express reference to international norms that guide integration of DRM and PHE is absent in domestic COVID-19 laws and regulations, but the policy rationale supporting domestic CoviD-19 legislation - specifically, the President's declaration of a state of calamity and a state of national emergency due to the unparalleled disruption of health, economic, and social functions, thereby triggering the use of DRM mechanisms - places the Bangkok Principles' key actions for managing biological hazards squarely in operation in the Philippines' response to the primary and secondary non-health impacts of the pandemic.

\footnotetext{
42 who, Health Emergency and Disaster Risk Management Framework (2019).

43 Ibid., Annex 2.

44 Emily Ying Yang Chan et al., 'Reflection of Challenges and Opportunities within the COVID-19 Pandemic to Include Biological Hazards into DRR Planning' (2021) 18/4 International Journal of Environmental Research and Public Health, 1614. 


\subsection{Fostering Coordination between DRM and Health under the Bangkok Principles}

The wHo Health-EDRM Framework focuses on addressing health risks as a consequence of disasters and, due to this limited objective, its components do not cover social protection measures beyond those required for health care. It also does not completely provide safeguard standards in the exercise of emergency public health measures apart from its emphasis on the right to information regarding the existing health risk.

These gaps can be addressed by the Bangkok Principles and broader international disaster law norms on disaster relief and other forms of welfare assistance, livelihood support and other measures for early recovery - elements which are crucial in addressing the widespread non-health impacts of coviD19. Establishing DRM and health coordination, either in disaster laws or in public health laws, opens up investments for health emergency preparedness. This helps address 'a systematic lack of investments in public health emergency preparedness ${ }^{46}$ by institutionalising the Bangkok Principles in domestic PHE and disaster laws.

\section{5 Conclusion}

While there is a general observation that national DRM legal and policy frameworks do not sufficiently address biological hazards ${ }^{47}$ as part of a multihazard approach, the Philippines' experience shows that integration of DRM and public health principles in PHE legislation is feasible. This kind of hybrid legislation can maximise existing mechanisms and resources when it enables public health coordination platforms to leverage existing DRM structures, and when it enables the use of DRM funds as part of a larger pool of PHE funds. These are the factors that have helped avoid unnecessary silos between these two sectors both at the national and local levels of government.

46 Tea Collins et al., 'Addressing the double burden of the COVID-19 and noncommunicable disease pandemics: a new global governance challenge' (2021) 26/2 International Journal of Health Governance, 199-212.

47 See Giulio Bartolini, 'The Failure of 'Core Capacities' under the WHO IHR', in 70 International Comparative Law Quarterly (2021), which suggested that 'paradigms pertaining to international disaster law could integrate preparedness measures related to the IHR within their broader frameworks', and noted that 'biological risks are normally not yet fully integrated into national disaster risk reduction strategies'. 